\title{
Reviewing Influence of Information Asymmetry on Corporate Tax Avoidance
}

\author{
Manijeh Kord Manjiri' and Mahdi Ahmadipanah ${ }^{2 *}$ \\ 'Department of Accounting, Alborz Science and Research Branch, Islamic Azad University, Hashtgerd, Iran \\ ²Department of Management, Payame Noor University (PNU), P.O. Box, 19395-3697, Tehran, Iran; ma_ah_pa@yahoo.com
}

\begin{abstract}
Aim of this study is to review relationship between information asymmetry and tax avoidance in firms listed in Tehran Stock Exchange. To this end, 121 firms from listed firms in Tehran Stock Exchange have been selected using a screening technique during the years 2005-2015. The data have been analyzed either in pool or panel. In this study, Levin, Lane and Chou test have been used to determine the reliability of the research variables. And the independent, dependent and control variables of the research during the research period have been stable which is tested by components of F Limer and Hausman tests and multivariate regression used for hypotheses tests. The dependent variable of this research is tax avoidance, which has been used to measure three effective tax rates, effective tax rates and permanent tax disputes. The results show that there is a negative and significant relationship between information asymmetry and effective tax rate, between information asymmetry and effective tax rate, and between asymmetric information of permanent tax dispute, relationship is negative and significant.
\end{abstract}

Keywords: Effective Tax Rate, Information Asymmetry, Tax Avoidance

\section{Introduction}

Tax revenues are one of the most important and reliable sources of government revenue. Increasing tax revenues and reducing dependency on oil revenues, reduce class divisions in society, and destructive effects of the ineffective economic outcomes, including inflation. If tax justice is realized, that is to say, the entire economy is taxed and there is no tax evasion, it can reduce the adverse and harmful distributional effects and increase liquidity ${ }^{14}$. As tax avoidance can increase the company's value after tax, on the other hand, due to a conflict of interests between managers and shareholders, it can create ambiguity in the company's activities and provide grounds for diversion of interests by managers, which, in the case of the existence of reward incentives for the manager can be reduced. Tax avoidance plans can lead to tax savings for the company. However, it is always possible to increase the ambiguity of financial activities of the company due to bold tax planning to hide the facts in order to prevent taxpayers from losing money ${ }^{3}$.

For the first time in 1970, the theory of information asymmetry was presented by Akerlofand et al., (1970). Researchers have shown that information asymmetry can increase the Contradictory of the markets, which occurs before the transaction takes place. Information asymmetry depict a market in which the seller has more information than the buyer. Information asymmetry in a simple statement suggests that everyone does not have access to information in the same way, and management has more information than others in their own position, and in fact is the main driver in directing managers toward profit management ${ }^{30}$. One of the effects of asymmetric information is disturbing market performance. The more information asymmetry in a market is, the less efficient it will be, and the ratio of the number of successful exchanges will be reduced ${ }^{28}$. One of the problems of representation is information asymmetry that is created in a non-transparent information environment. One of the problems of representation is asymmetry of information that increases in the non-transparent information environment and can affect the amount of cash-flow outflows, including tax evasion. Accordingly, in this study we examine effect of information asymmetry on tax evasion. In this section, generalities of the research include the expression of the problem, the need for research and the objectives described.

${ }^{*}$ Author for correspondence 


\section{Research Literature}

\subsection{Theoretical Background}

One of the important points about stock exchanges is issue of market efficiency, according to which all market information reflects its effect on stock prices (Chen \& Lin, 2010). From the viewpoint of efficient market hypothesis, it may be possible to explain the existence of accounting as information asymmetry in which one of the parties to transaction has more information than the other party. This is due to intragroup transactions and information. In capital markets, many investors are ordinary people and only way to access important information is through announcements from firms ${ }^{4}$. According to Scott et al., (2003), when one of the parties in transaction has an information advantage over the other side, the economic system is asymmetric from the information viewpoint. In accounting theory, the issue of asymmetry of information is important because securities markets face the same problems as information asymmetry, due to the existence of in-organization information. Even if the price fully reflects all market information to everyone, it is still possible for individuals inside the organization to have more information than non-members ${ }^{19}$. At this time, these people are taking advantage of having information and gaining more benefits. When foreign investors are aware of this issue, it is obvious that they will not pay the amounts they were prepared to pay for securities in the event of full information, and thus, against potential losses ${ }^{25}$.

Chang et al., (2006) Stated that in firms whose shareholders are form entities and other firms, valuable internal information about the company's future prospects such as its business strategies, transfer through direct communication between the managers and the owners of the firms. This transfer of information is often provided by shareholder channels through channels similar to the members of the board of directors, and by this way most investors access this information. Therefore, prevalence of corporate ownership by other firms can play a key role in reducing the asymmetry of information between executives and outsourced investors and, as a consequence of market capitalization of their information (Chen \& Lin, 2010). On the other hand, in most countries, most of the government's revenue sources come from taxes. The share of total public revenues varies among countries. Meanwhile, avoiding and tax evasion in countries has led to lower tax revenues for countries than is estimated amount. So, among the most important issues that are currently being considered in most studies, is tax evasion and avoidance, and factors that affect it, and the results it achieves. From a theoretical point of view, tax avoidance is an attempt to reduce tax payments ${ }^{14}$. Tax evasion is a kind of legal offense, but tax evasion, is in fact a kind of legal vacuum in tax laws to reduce taxes. Therefore, since tax evasion is an apparently legal activity, it appears that it is more exposed than tax evasion, and because tax avoidance is within a certain range for the use of tax benefits, and mainly restrictive rules on avoidance controls There is no tax. Therefore, many firms appear to be involved in tax avoidance, and it is therefore important to determine the factors influencing tax avoidance in firms (Chen and Lin, 2010).

What factors affect tax avoidance? This is a question that is important throughout the world both from the academic standpoint and from policymaker's point of view. Firms in many parts of the world, including the largest firms, have been criticized for tax evasion. The issue of tax evasion has received limited attention from other investigations. The existence of inaccurate information leads to tax avoidance in firms, while financial information and transparent markets provide significant assistance in avoiding tax avoidance ${ }^{11}$. In spite of this, managers sometimes use the methods chosen for tax purposes for financial reporting and vice versa, whose benefits are greater than their costs. One of the benefits of this work is to avoid additional investigations and potential criminal offenses from the tax organization. But this procedural consistency may also involve non-monetary costs. For example, the use of the first outflow from the first entry for inventories may result in a lesser indication of the profit and, consequently, the tax in question, which benefits or benefits, Keeping more cash for the company. But, on the other hand, lower profits from the perspective of corporate creditors may lead to higher interest rates for firms ${ }^{6}$. The result of the application and consideration of the benefits and costs by management results in a difference between the profit before tax reported in the event of a profit and loss and taxable profit (tax accounting difference) ${ }^{34}$. Therefore, how to estimate taxable profits, or more precisely, the tax and tax accounting differences are among the most important factors that can be used to measure tax avoidance (Chen and Lin, 2010).

Rego (2003) Defined the avoidance of tax as the use of tax planning methods that legally reduce corporate income tax payments. Tax avoidance is generally defined by the apparent tax cut (Hanlon \& Heitzman, 2010). Tax avoidance activities are commonly referred to tax saving tools that transfer resources from government to shareholders and therefore increase the value after tax of the company ${ }^{10}$. In recent years, mass media and lawmakers have called for more transparency from firms in tackling tax evasion. Although studies in the last two decades have identified tax avoidance as related to different factors, little research has been done on information transparency. Asymmetric information that forms the center of corporate finance is linked to avoiding tax payments for the following reasons: First, firms with high-transparency information will hide income and profits through a complex financial structure and hard-core tax shields. This means that the trading costs 
of these firms will be high to avoid paying taxes. Secondly, high transparency increases direct tax avoidance, which is an increase in the likelihood of identification by tax authorities and investors, which in turn leads to increased costs of management reputation and worries ${ }^{20}$. In addition, increasing the likelihood of identifying increases the company's concern about the potential increase in financial costs. And as a final point to note, increasing transparency in financial terms can prevent incentives to anticipate corporate tax evasion (Chen \& Lin, 2014). Based on the content of this research, we seek to answer this question as to whether there is a meaningful relationship between information asymmetry and tax avoidance in the firms listed to the Tehran Stock Exchange?

\subsection{Experimental Background}

Chen and Lin (2014) used analysts' coverage as a tool for measuring information asymmetry, and the results show that there is a significant negative correlation between this variable and tax evasion. The results also show that the impact is due to the low coverage of analysts and financial constraints. Hanlon et al., (2014) concluded that contracts involving the sharing of information across the country with tax agencies would reduce tax evasion. Mojtahed Zadeh et al., (2015) influenced the impact of corporate disclosure on tax evasion. The results of the research show that corporate disclosure quality has a positive and significant impact on corporate tax avoidance. Babajani et al, 2014 state that accounting standards provide a significant flexibility in the application of accounting methods for financial reporting. Existing research and empirical evidence suggests that most firms are involved in some kind of profit management process. Examines one of the main prerequisites for profit management, namely, information asymmetry between managers and investors. The results of this research indicate that information asymmetric index, which is a combination of five criteria, has a positive and significant effect on earnings management.

Balakrishnan et al., (2012) bold tax procedures, investigated the transparency of the company and showed that information asymmetry, earnings quality and forecasting errors by analysts are used as a measure of corporate transparency, and a bold tax strategy reduces transparency of the company. Armstrong et al., (2012) explored and explained the incentives for tax planning. The aforementioned individuals used a dedicated dataset containing details of bonus schemes in a partial manner. The findings of this research indicate that there is a negative and significant relationship between incentive schemes for remunerative directors with an effective tax rate calculated based on accounting standards, but there is a weak relationship between these schemes and other criteria used. Hanlon \& Heitzman (2010) examined the factors influencing tax evasion. The researchers have argued that the agents are not explicitly identified and require more research. Chen et al., (2010) showed that tax evasion is positively related to the risk of falling stock prices. This result is consistent with the view that tax avoidance, the ability to eliminate management benefits and hide bad news through providing tools and areas for this opportunistic behavior, is consistent. ${ }^{8}$ Showed that the range of the proposed bid and offer price difference as a measure of transparency of the company and the difference in accounting profit and taxable profit as a tax avoidance criterion are used, and the higher the avoidance of tax payments, the amount There is more ambiguity in that company.

Rahmani \& Arbabi Bahar (2013) examine the relationship between diagnosis and tax evasion with profit management and tax evasion. The results show that there is a positive and significant relationship between the difference between the tax and the tax evasion with profit management and avoidance of taxes. Rostaee dare miane et al (2015) states that the company's business strategy reflects how the company is competitive in its chosen market. A firm can use policies and activities to strengthen its business strategy, which can provide them with a sustainable competitive edge in their preferred market. Since the company's strategies are based on the company's willingness to deal with risk and uncertainty, so the strategy that the company chooses can affect the level of tax evasion. Hence, in this research, the relationship between business strategy and tax evasion is discussed. Dyrenget al., (2010) examined the effective rate of long-term cash tax to test corporate tax avoidance. The results of their research showed that there is a significant cross-sectional difference in tax avoidance by firms, and nearly $85 \%$ of firms have the ability to keep the effective tax rate below $81 \%$. Mayberryet al., (2012) examined the taxable income smoothing, tax avoidance, and tax-deductible information content. They have used the effective tax rate and effective tax rate as tax avoidance measures. The results showed that there is a positive and significant correlation between taxable income smoothing and avoidance of future taxes. There is also a negative and meaningful relationship between taxdeductible tax revenue and its informational content; in other words, tax-deductible tax smoothing reduces its information content.

Akins et al. (2012) examined relationship between knowledge competitions of informed investors. They used two criteria for the number and concentration of institutional ownership to measure information competition. Their research results show that with increasing information competition between knowledgeable investors, the information asymmetry pricing is reduced. Mousavian and Kordestani (2013) state that information competition is defined as a competition between knowledgeable investors in the trading and sharing of confidential information. The results of estimating multiple linear regression models using cross-sectional data show that 
with the increase in the number of institutional owners as a criterion for information competition, information asymmetry pricing is reduced. According to research evidence, the impact of institutional ownership concentration as the other criterion of information competition in this research is not confirmed by the pricing of information asymmetry. Foroughi et al. (2012) used the difference in profits and fixed income tax expense as a tax evasion rate. The results of the study showed that tax evasion leads to the risk of future stock price collapse. In this sense, when a company performs tax evasion activities, because these activities require the use of an obscure and complex reporting system, the ability of managers to maintain and maintain negative information inside the company and, consequently, the risk of stock price crash will increase. Pourheidari and Barhaninejad (2012) state that characteristics of company's strategic principles in their research included the size of the board of directors, the composition of the board of directors, the duplicity of the director and size of the audit firm. Their results indicated a negative relationship between the composition of the board of directors and the size of the audit firm with the tax administration. They also stated that there is a positive correlation between CEO dichotomy and tax administration. However, there was no significant relationship between the size of the board of directors and the tax administration.

Jacobson and Aaker (1993) have reviewed comparative information asymmetry between the Japanese and US capital markets. Their research results showed that the Japanese capital market reflects future profitability data earlier than the US stock market in stock prices. Because of the corporate ownership structure and the widespread presence of institutional shareholders, Japanese shareholders are better aware of future prospects than Americans Jiang \& Kim (2000) examine the effects of information asymmetry between managers and shareholders in terms of profitability in terms of time and quantity. As the level of institutional ownership increases, there will be less information asymmetry between corporate executives and other relevant market players. Therefore, in firms with more corporate ownership, stock market prices include information related to the company's future profitability faster than firms that have less corporate ownership.

\section{Research Hypotheses and Models}

\subsection{Hypothesis 1}

There is a positive and significant relationship between information asymmetry and tax avoidance (effective tax rate).

\footnotetext{
$1-E_{\text {it }}=\alpha_{0}+\alpha_{1} \mathrm{RS}_{\mathrm{it}}+\alpha_{2} \operatorname{Size}_{\mathrm{it}}+\alpha_{3} \operatorname{Lev}_{\mathrm{it}}+\alpha_{4} \mathrm{DVOL}_{\mathrm{it}}+\alpha_{5}$ DTU $\mathrm{it}_{\text {it }}+\alpha_{6} \mathrm{MV}_{\text {it }}+\alpha_{7} \mathrm{DN}_{\mathrm{it}}+\alpha_{8}$ Volatility $_{\text {it }}+\alpha_{9}$ Grow $_{\text {it }}+\varepsilon_{\text {it }}$
}

\subsection{Hypothesis 2}

There is a positive and significant relationship between information asymmetry and tax evasion (effective tax rate).

$1-\mathrm{CETR}_{\mathrm{it}}=\alpha_{0}+\alpha_{1} \mathrm{RS}_{\mathrm{it}}+\alpha_{2} \operatorname{Size}_{\mathrm{it}}+\alpha_{3} \operatorname{Lev}_{\mathrm{it}}+\alpha_{4} \mathrm{DVOL}_{\mathrm{it}}+\alpha_{5}$ $\mathrm{DTU}_{\mathrm{it}}+\alpha_{6} \mathrm{MV}_{\mathrm{it}}+\alpha_{7} \mathrm{DN}_{\mathrm{it}}+\alpha_{8}$ Volatility $_{\mathrm{it}}+\alpha_{9} \mathrm{Grow}_{\mathrm{it}}+\varepsilon_{\mathrm{it}}$

\subsection{Hypothesis 3}

There is a positive and significant relationship between information asymmetry and tax avoidance (permanent tax disagreements).

$\mathrm{BTD}_{\mathrm{it}}=\alpha_{0}+\alpha_{1} \mathrm{RS}_{\mathrm{it}}+\alpha_{2} \mathrm{Size}_{\mathrm{it}}+\alpha_{3} \mathrm{Lev}_{\mathrm{it}}+\alpha_{4} \mathrm{DVOL}_{\mathrm{it}}+\alpha_{5}$ $\mathrm{DTU}_{\mathrm{it}}+\alpha_{6} \mathrm{MV}_{\mathrm{it}}+\alpha_{7} \mathrm{DN}_{\mathrm{it}}+\alpha_{8}$ Volatility $_{\mathrm{it}}+\alpha_{9} \mathrm{Grow}_{\mathrm{it}}+\varepsilon_{\mathrm{it}}$

RS: Information asymmetry

1-CETR: Cash effective tax rate,

Size: Firm Size,

DVOL: Rial Volume Daily Trading,

Volatility: stock return variability, MV:Corporate Market Value, cit: Error Value,

\section{Research Variables}

In this research, dependent variables include the effective tax rate, Cash effective tax rate, and permanent tax disputes. The independent variable of the research is information asymmetry and control variables including company size, financial leverage, growth opportunities, Rial volume of daily deals, daily turnover of shares of the company, Frequency of daily stock trading and stock return variability.

\subsection{Independent Variable}

In this research, we use a model for measuring information asymmetry between investors, which Venkatesh and Chiang (1986) have designed to determine the range of bid price differentials. This pattern has been used in numerous research. In Iran, Ahmadpour and Rasaiyan (2006), Reza Zadeh and Azad (2008), Ahmadpour and Ajam (2010), Ghorbani and Adeli (2012) and others have used this template to measure information asymmetry. This template is as follows:

$$
\mathrm{RS}=\frac{\mathrm{AP}_{\mathrm{it}}-\mathbf{B P}_{\mathrm{it}}}{\left(\mathrm{AP}_{\mathrm{it}}+\mathrm{AP}_{\mathrm{it}}\right) / \mathbf{2}} \times 100
$$

RS: Discount bid for buying and selling shares of the company 
AP: The average selling price of a company's stock in period $t$

BP: The average bid for a company's shares $i$ during the period $t$

According to this model, the higher the price difference between buying and selling a larger number of stocks, the more information is asymmetric. In the test of hypotheses, the absolute value of the number obtained from this pattern is used.

\subsection{Dependent Variables}

The dependent variable of this research is tax avoidance of firms. To this end, three alternative measures are used to measure tax avoidance, which are as follows:

1-ETR it: effective tax rate; from the company's tax expense dividend in year $t$, on income before tax, $\mathrm{i}$ in year $\mathrm{t}$.

1-CETR $\mathrm{it}_{\mathrm{it}}$ Cash effective tax rate; the amount of cash tax paid (paid) by $\mathrm{i}$ in year $\mathrm{t}$ to the pre-tax income of company $\mathrm{i}$ in year $\mathrm{t}$

$\mathrm{BTD}_{\mathrm{it}}$ : Permanent tax disputes; Income before tax for company $i$ in year $t$ and tax revenue, divided by total assets of the company at the beginning of period t. Tax revenue is also derived from the division of the tax on the tax rate (22.5\%) (according to Article 105 of the Direct Tax Code).

\subsection{Control Variables}

\subsubsection{Size of the Company}

In this research, the size of the company is the size of the assets, and for this purpose, the logarithm of the company's assets has been used at the end of the year.

\subsubsection{Financial Leverage}

The debt maturity structure can affect agency costs. Short-term debt can be more beneficial than long-term debt to reduce issues related to free cash flow. Myers (1997) the owner and manager can be reduced through short-term borrowing. In this research, Floraica's research Feloxis (2008) uses the ratio of short-term debt to total debt.

\subsubsection{Rial Volume of Daily Stock Trading}

The average Rial volume of the company's stock trades was calculated during the year, and then its natural logarithm was used as the variable.

\subsubsection{Daily Turnover of the Company's Shares}

The share turnover ratio is defined as the number of shares traded throughout the year divided by the total number of shares issued by the company. The figures obtained for the different days are averaged.

\subsubsection{Market Value of the Company}

The market value of the company is derived from the product of the number of shares issued by the company in the market share market share per day. Then the mean of that logarithm is taken and used in the model.

\subsubsection{Frequency of Daily Trading of Shares}

By calculating the average number of times each day for each year.

\subsubsection{Stock Returns Variability}

Stock return variability has been measured by the standard deviation of 12-month stock returns.

\subsubsection{Growth Opportunities}

To measure the growth index, such criteria as growth in current assets, growth in fixed assets, sales growth and gross profit growth, the proportion of capital expenditures divided by total assets are also used ${ }^{16}$. In this research, Gani et al. Used the ratio of expenditures to total assets.

\section{Selected Sample and Statistical Community}

This research methodology is a post-event type correlation. To test the hypotheses, the multivariate regression model has been used for the panel data type (cross-sectional). The statistical population of this research is all firms accepted in Tehran Stock Exchange during the period of 2005-2015. In this research, a non-probabilistic target sample was used to select a sampling method. In an unplanned sampling plan, members of the statistical community are selected to match the criteria or criteria that the researcher intends to take. In this research, the sample is started with the entire statistical society and after considering the following conditions; these limits include their financial period ending on March 29; each company should have sufficient data in all years 2005-2015, that is, During the entire period of this period, actively participate in the Tehran Stock Exchange; each company will be traded for at least six months each year, and the selected variables will be available in this research. Based on these criteria, 86 firms were selected as the final statistical sample.

\section{Findings of the Research}

\subsection{Descriptive Statistics}

In descriptive analysis, the researcher describes collected data using descriptive statistics tables and indicators such as central 
indexes and dispersion. This contributes to the clarity and explanation of research data. The results of descriptive analysis of data are presented in Table (1).

Descriptive statistics for 121 firms during the period of 2005-2015 are presented in the table below. The average effective tax rate is equal to 0.252 and the average effective tax rate is 0.271 and the permanent tax disbursement is 0.265 , which is the deviation from the legal rate expressing the tax planning activities. Information gap asymmetries equal to 0.254 are due to the ineffectiveness of Tehran Stock Exchange, the more information is different. Other information is described in the (Table 1) above.

\subsection{Investigating the Reliability and Reliability of Research Variables}

The results of the reliability of the research variables are presented in Table (2). To determine the reliability of the research variables, Levine, Lane and Chu tests were used. The results of this test indicate that the independent, dependent and control variables of the research during the research period were stable. Because the P value for the test was less than $5 \%$. Reliability means that the mean and variance of variables over time and covariance of variables have been constant between different years.

\subsection{Testing the First Hypothesis}

According to Table (3), the probability of the F lemmer's statistic is less than the significant level of $5 \%$ and therefore, for testing the first hypothesis, the use of the combined data method is discarded. Accordingly, the Hausman test according to Table (3) is less than the significant level of $5 \%$. Therefore, we have sufficient reason to reject the pattern of random effects, and to test the first hypothesis we use a constant effect pattern.
Table 2. Reliability of research variables

\begin{tabular}{|l|l|l|}
\hline LLC probability & LLC statistic & Variable \\
\hline 0.000 & -32.3116 & RS \\
\hline 0.000 & -36.1856 & 1 -ETR \\
\hline 0.000 & -23.5918 & 1 -CETR \\
\hline 0.000 & -35.3738 & BTD \\
\hline 0.000 & -29.4928 & Size \\
\hline 0.000 & -38.5218 & Lev \\
\hline 0.000 & -35.3714 & DVOL \\
\hline 0.000 & -29.3219 & DTU \\
\hline 0.000 & -33.7947 & Volatility \\
\hline 0.000 & -44.5316 & DN \\
\hline 0.000 & -38.9752 & MV \\
\hline 0.000 & -26.0411 & Grow \\
\hline
\end{tabular}

The combined regression model has a significant effect on the impact of information asymmetry on tax avoidance (effective tax rate), negative (0.054) and significant level (0.021). This suggests that information asymmetry has a negative and significant impact on the effective tax rate. Meanwhile, the significance level calculated for the control variables shows that the firm's size, financial leverage has a significant relationship with the effective tax rate, and the significant level calculated for the variability variables of stock return, Rial volume of transactions, daily turnover of shares, market value, The number of transactions and growth opportunities have a significant relationship with the effective tax rate.

The results of the F-statistic show that the model is significant in general and, according to the Durbin-Watson statistics (1.99), there is no correlation problem. The reported inflation factor for variance is less than 5 and more than one, indicating that there is no linear relationship between

Table 1. Results of descriptive analysis of research data

\begin{tabular}{|l|l|l|l|l|l|l|l|l|}
\hline Kurtosis & Skewness & Standard deviation & mean & average & Min & Max & N & Variable \\
\hline 2.561 & 1.064 & 0.381 & 0.237 & 0.254 & -0.953 & 3.154 & 1210 & RS \\
\hline 2.748 & 1.064 & 0.129 & 0.317 & 0.252 & 0.154 & 0.439 & 1210 & 1 -ETR \\
\hline 2.615 & 1.157 & 0.098 & 0.294 & 0.271 & 0.046 & 0.513 & 1210 & 1 -CETR \\
\hline 2.742 & 1.437 & 0.296 & 0.039 & 0.265 & 0.038 & 0.559 & 1210 & BTD \\
\hline 2.974 & 1.194 & 1.254 & 11.868 & 12.647 & 8.619 & 18.641 & 1210 & Size \\
\hline 2.154 & 1.254 & 0.148 & 0.417 & 0.394 & 0.148 & 0.715 & 1210 & Lev \\
\hline 3.048 & 1.421 & 1.017 & 8.167 & 8.014 & 5.417 & 10.14 & 1210 & DVOL \\
\hline 1.024 & 0.189 & 0.006 & 0.002 & 0.003 & 0.0001 & 0.094 & 1210 & DTU \\
\hline 2.130 & 1.124 & 1.021 & 11.029 & 11.164 & 8.215 & 14.311 & 1210 & Volatility \\
\hline 3.617 & 2.157 & 8.314 & 29.174 & 49.612 & 2.614 & 427.31 & 1210 & DN \\
\hline 2.743 & 1.019 & 1.624 & 10.314 & 13.154 & 0.000 & 80.317 & 1210 & MV \\
\hline 2.418 & 1.193 & 0.167 & 0.296 & 0.337 & 0.089 & 0.667 & 1210 & Grow \\
\hline
\end{tabular}


independent variables and does not require conversion (the natural logarithm of the variables). Considering the probability of Jarque-Bera (0.1159), the dependent variable has a normal distribution. Because its value is greater than 0.05 , the assumption of zero is not based on the normalization of the dependent variable and the dependent variable is normal. In addition, the results of the adjusted coefficient of determination indicate that, in the entire research period, the research scope is 0.53 of the effective tax rate changes influenced by the independent and control variables of the research. Given the negative and significant impact of information asymmetry on the effective tax rate, the first hypothesis is not confirmed and there is no positive and significant relationship between information asymmetry and effective tax rate.

\subsection{Testing the Second Hypothesis}

According to Table (4), the probability of the statistic of the F lemmer is less than the significant level of $5 \%$ and therefore, to test the first hypothesis, the use of the combined data method is discarded. Accordingly, the value of Husman test according to Table (4) is less than the 5\% significance level. Therefore, we have enough reason to reject the pattern of random effects and use the fixed effect pattern to test the first hypothesis.

The combined regression model has a significant effect on the effect of information asymmetry on the effective tax rate, negative (0.049) and significance level (0.017). This suggests that information asymmetry has a negative and significant effect on the effective rate of tax cash. Meanwhile, the significance level calculated for the control variables shows that the firm size, financial leverage has a significant relationship with the effective tax cash rate and the significant level calculated for variables of variability of stock returns, Rial volume of transactions, daily turnover of shares, market value, The frequency of transactions and growth opportunities have a significant relationship with the effective rate of tax cash.

The results of the $\mathrm{F}$ statistic indicate that the model in general is significant and is not correlated with the camera-Watson $(2 / 05)$ statistics. According to Watson camera statistics has no problem with self-correlation. The reported inflation factor for variance is less than 5 and more than one, indicating that there is no linear relationship between independent variables and does not require conversion (the natural logarithm of the variables). Regarding the probability of the Jarque-Bera statistics (0.1285), the dependent variable has a normal distribution. Because its value is greater than 0.05 , the assumption of zero is not based on the normalization of the dependent variable and the dependent variable is normal. In addition, the results of the adjusted adjustment coefficient indicate that, over the entire study period, 0.55 of the effective tax rate changes are affected by the independent and control variables of the research. Considering the negative and significant effect of information asymmetry on the effective rate of tax cash, the second hypothesis is not confirmed and there is no positive and significant relationship between information asymmetry and effective tax cash rate.

\subsection{Examination of Third Hypothesis}

According to Table (5), the probability of the probability of the F lemmer less than the significant level of $5 \%$ and therefore,

Table 3. Test results of the first hypothesis

\begin{tabular}{|l|l|l|l|l|}
\hline Probability of test & df & Test statistic & Test type & Test type \\
\hline 0.0011 & 119,1190 & 2.673 & F limer & Pool/panel \\
\hline 0.0009 & 3 & 19.639 & Hausman & Stable effects pattern against random \\
\hline statisticVIF & t- probability & t-statistic & Regression coefficients & variables \\
\hline- & 0.059 & 1.79 & 0.086 & Fixed value \\
\hline 1.791 & 0.022 & -2.83 & -0.054 & RS \\
\hline 1.938 & 0.044 & 2.45 & 0.093 & Size \\
\hline 1.799 & 0.024 & -2.69 & 0.074 & Lev \\
\hline 2.028 & 0.022 & -2.73 & -0.069 & DVOL \\
\hline 1.789 & 0.011 & -3.09 & -0.038 & DTU \\
\hline 1.848 & 0.039 & -2.69 & -0.071 & Volatility \\
\hline 1.949 & 0.034 & -2.68 & -0.075 & DN \\
\hline 1.894 & 0.015 & -2.98 & -0.046 & MV \\
\hline 1.795 & 0.037 & -2.67 & -0.076 & Grow \\
\hline Jarque-Bera Probability & 0.0009 & F- probability & 0.57 & The coefficient of determination \\
\hline 0.1159 & 1.99 & Watson Camera Statistics & 0.53 & adjusted coefficient of determination \\
\hline
\end{tabular}


Table 4. Test results of the second hypothesis

\begin{tabular}{|l|l|l|l|l|}
\hline Probability of test & df & Test statistic & Test type & Test type \\
\hline 0.0005 & 119,1190 & 2.275 & F limer & Pool/panel \\
\hline 0.0008 & 3 & 19.546 & Hausman & Stable effects pattern against random \\
\hline statisticVIF & t- probability & t-statistic & Regression coefficients & variables \\
\hline- & 0.021 & 2.87 & 0.055 & Fixed value \\
\hline 1.95 & 0.017 & 2.94 & 0.045 & RS \\
\hline 1.87 & 0.047 & 2.45 & 0.091 & Size \\
\hline 1.62 & 0.029 & 2.69 & 0.070 & Lev \\
\hline 1.69 & 0.028 & -2.73 & -0.066 & DVOL \\
\hline 1.82 & 0.012 & -3.09 & -0.038 & DTU \\
\hline 1.75 & 0.018 & -2.69 & -0.069 & Volatility \\
\hline 1.79 & 0.037 & -2.68 & -0.071 & DN \\
\hline 1.55 & 0.018 & -2.98 & -0.044 & MV \\
\hline 1.84 & 0.039 & -2.67 & -0.072 & Grow \\
\hline Jarque-Bera Probability & 0.0006 & F- probability & 0.60 & The coefficient of determination \\
\hline 0.1285 & 2.05 & Watson Camera Statistics & 0.55 & adjusted coefficient of determination \\
\hline
\end{tabular}

for the first hypothesis test, the use of the combined data method is discarded. Accordingly, the value of Husman test according to Table (5) is more than the significant level of $5 \%$. Therefore, we do not have enough reason to reject the pattern of random effects. To test the first hypothesis, we use the random effects pattern. The combined regression model of the random effects of the effect of information asymmetry on the permanent tax disagreement (0.043) and significance level $(0.013)$ is significant. This suggests that information asymmetry has a significant negative effect on the permanent tax disagreement. Meanwhile, the significance level calculated for the control variables shows that the firm size, financial leverage has a significant relationship with the permanent tax disagreement and the significant level calculated for variables variability of stock returns, volume of transactions, daily turnover of shares, market value, The number of transactions and growth opportunities have a significant relationship with the permanent tax disagreement.

The results of the F statistics (0.0005) also show that the model is in general. According to Watson Camera Statistics (2.12), there is no problem of self-correlation. One of the ways to conduct a linear study is to calculate the inflation factor of variance. The reported inflation factor for variance is less than 5 and more than one, indicating that there is no linear relationship between independent variables and does not require conversion (the natural logarithm of the variables). Considering the probability of Jarque-Bera statistics (0.1647), the dependent variable has a normal distribution. Because its value is greater than 0.05 , the assumption of zero is not based on the normalization of the dependent variable and the dependent variable is normal. In addition, the results of the adjusted coefficient of determination indicate that 0.61 of the changes in the permanent tax dispute are affected by the independent and control variables of the research throughout the research period. With regard to the negative and significant effect of information asymmetry on the permanent difference in tax, the third hypothesis is not confirmed and there is no positive and significant relation between information asymmetry and permanent tax disagreement.

\section{Conclusion}

In firms, income tax expense is one of the most important costs, and firms often see it as a cost that they should not pay because they pay off the company's liquidity tax, and remaining cash and cash for other stakeholder participation, including shareholders. Naturally, therefore, there is a motive for firms and their shareholders to avoid paying taxes through their directors. However, avoiding tax or, in other words, tax minimization, leads to an increase in the remaining funds for company shareholders, but based on evidence, tax avoidance activities can provide managers with the opportunity to avoid tax avoidance activities. In order to increase the value of the company and develop its opportunistic actions in order not to disclose these news within the company. Based on the basic assumptions of the representation theory, there is a potential conflict of interest between the owner and the representative. Consequently, different control mechanisms are designed to deal with such an inconsistency. The control mechanisms of the company are tools that drive corporate governance efforts 
Table 5. Test results of the third hypothesis

\begin{tabular}{|l|l|l|l|l|}
\hline Probability of test & df & Test statistic & Test type & Test type \\
\hline 0.0021 & 119,1190 & 8.71 & F limer & Pool/panel \\
\hline 0.0937 & 3 & 31.34 & Hausman & Stable effects pattern against random \\
\hline statisticVIF & t- probability & t-statistic & Regression coefficients & variables \\
\hline- & 0.0832 & 1.57 & 0.095 & Fixed value \\
\hline 1.67 & 0.016 & $11 / 3$ & 0.043 & RS \\
\hline 1.93 & 0.047 & 2.41 & 0.091 & Size \\
\hline 1.59 & 0.037 & 2.49 & 0.089 & Lev \\
\hline 2.04 & 0.029 & 2.68 & 0.072 & DVOL \\
\hline 1.69 & 0.019 & 2.77 & 0.057 & DTU \\
\hline 1.77 & 0.043 & 2.88 & 0.066 & Volatility \\
\hline 1.58 & 0.031 & 2.77 & 0.076 & DN \\
\hline 1.75 & 0.038 & 2.92 & 0.053 & MV \\
\hline 1.77 & 0.024 & 2.89 & 0.048 & Grow \\
\hline Jarque-Bera Probability & 0.0005 & F- probability & 0.63 & The coefficient of determination \\
\hline 0.1647 & 2.12 & Watson Camera Statistics & 0.61 & adjusted coefficient of determination \\
\hline
\end{tabular}

to align with the interests of investors. Disclosed information, as part of a control mechanism, has helped investors to discipline managers of venture capital firms, encouraging managers to take steps in the interests of shareholders and improve company performance.

Managers use methods selected for tax purposes for financial reporting and vice versa, where benefits outweigh costs. One of benefits of this work is to avoid additional investigations and potential criminal offenses from the tax organization. But this procedural consistency may also involve non-monetary costs. For example, the use of the first outflow from the first entry for inventories may result in a lesser indication of the profit and, consequently, the tax in question, which benefits or benefits, Keeping more cash for the company. But, on the contrary, lower profits than the company's creditors' perspective may lead to higher interest rates for the company. The result of the application and consideration of the benefits and expenses by management results in a difference between profits before tax reported in the event of a profit and loss and taxable profit (tax accounting difference).

According to classic financial theory, in an efficient market, there is no role for financial disclosure, so there is no demand for accounting information. However, in the face of market imperfections such as information asymmetry and the issue of representation, financial reporting for effective contracts is necessary. Because of the inherent advantage of asymmetric information and flexibility in reporting, equity, shareholder wealth and management are interchangeable. Information asymmetry is created when shareholders do not have access to confidential information that corporate executives have.
The existence of sufficient market information and the timely and prompt reflection of information on the price of securities is closely related to market efficiency. In the efficient market, information that is being distributed on the market quickly impacts prices. In such a market, the price of securities is close to its intrinsic value.

Information symmetry exists when managers and market share the same information. Therefore, managers and the market will endure uncertainty about the company alike. But in the event of information asymmetry, managers have more and better information than the market because of the private and confidential information about the company. That means they have access to company information before the market is informed. The company's specific information is transmitted over time through disclosure events to the market. The market has some uncertainty about the company before it discloses. The information asymmetry of the company is equal to the total uncertainty about the company, because managers and the market are likely to be aware of the impact of market variables on the firm's value. Market reactions to profit declarations can be the first measure of company information asymmetry through disclosure. Information asymmetry can be determined by the information medium, the number of public notices and the number of transactions of the company, and also influenced by the behavior of managers or the market. For example, when a public announcement is made about a company, assuming that other factors are fixed, the market may become more aware of company's actual situation and the information asymmetry will be reduced. The results of this research are in line with the results of Chen 
and Lin (2014), Balakrishnan et al., (2012), Armstrong et al., (2012), Chen et al. (2010), Dyreng et al., (2010), Arbabi Bahar (2013), Pourheidari and Sarvestani (2013) and in contradiction with the results of researches by Hanlon \& Heitzman (2010), Chen et al. (2009).

It is suggested to tax authorities that measures be taken to change the structure of tax system in order to lower tax burden on firms, thereby reducing corporate tax avoidance and resulting adverse effects. Also, given theoretical foundations and empirical research, it is recommended that managers and decision makers take into account the implications and potential impact of each tax policy in tax decisions and strategies, while taking into account long-term vision. It is also recommended that investors, while paying attention to corporate tax strategies and planning, address the potential consequences of future cash flows and corporate performance and consider relevant information in their decision making model. It is proposed to examine impact of ownership on tax policies and corporate tax avoidance, corporate tax avoidance and corporate social responsibility.

\section{Resources}

1. Akins B, Ng J and Verdi R. Investor competition overinformation and the pricing of information asymmetry, The Accounting Review. 2012; 87(1):35-58. https://doi.org/10.2308/accr-10157

2. Akerlof G, Michael Spence and Joseph Stiglitz. Markets with Asymmetric information. 1970. Available from: http://www. Nobelprize.org $\backslash$ Economist

3. Armstrong SC, Blouin LJ, Larker FD. The Incentives for Tax Planing. Journal of Accounting and Economics. 2012; 53:391411. https://doi.org/10.1016/j.jacceco.2011.04.001

4. Babajani Ja'far, Tahriri Arash, Saghafi Ali, Badri Ahmad. The Relationship Between Information Asymmetry and Earnings Management. Journal of Accounting Progress of Shiraz University. 2014; 6(2):1-26.

5. Balakrishnan K, Blouin J \& Guay W. Does Tax Aggressiveness Reduce Financial Reporting Transparency? 2012. Available at SSRN 1792783.

6. Bens DA and Monahan SJ. Disclosure quality and the excess value of diversification. Journal of Accounting Research 2004; 42:691-730. https://doi.org/10.1111/j.1475-679X.2004.00154.x

7. Chang $X$, Dasgupta $S$ and Hilary G. Analyst coverage and financing decisions. The Journal of Finance. 2006; 61:3009-48. https://doi.org/10.1111/j.1540-6261.2006.01010.x

8. Chen Y, Huang SH, Pereira R \& Wang J. Corporate Tax Avoidance and Firm Opacity. Discussion Paper. 2009.

9. Chen S, Chen X, Cheng Q and Shevlin T. Are family firms more tax aggressive than non-family firms? Journal of Financial Economics. 2010; 95:41-61. https://doi.org/10.1016/j. jfineco.2009.02.003
10. Desai MA and Dharmapala D. Corporate tax avoidance and high-powered incentives. Journal of Financial Economics. 2006; 79:145-79. https://doi.org/10.1016/j.jfineco.2005.02.002

11. Desai MA and Dharmapala D. Corporate tax avoidance and firm value. Review of Economics and Statistics. 2009; 91:537-46. https://doi.org/10.1162/rest.91.3.537

12. Dyreng SD, Hanlon M and Maydew EL. The effects of executives on corporate tax avoidance. The Accounting Review. 2010; 85:1163-89. https://doi.org/10.2308/accr.2010.85.4.1163

13. Foroughi D, Ahmadi N. Investigating the Relationship Between the Composition of Shareholders and the Quality of Accruals in the Firms Listed in Tehran Stock Exchange. Accounting and Audit Research Quarterly. 2012; 5.

14. Hanlon M and Heitzman S. A review of tax research. Journal of Accounting and Economics. 2010; 50:127-78. https://doi. org/10.1016/j.jacceco.2010.09.002

15. Hanlon M, Maydew EL and Thornock JR. Taking the long way home: US tax evasion and offshore investments in US equity and debt markets. The Journal of Finance. 2014. forthcoming.

16. Guney Y, Li L \& Fairchild R. The relationship between product market competition and capital structure in Chinese listed firms. International Review of Financial Analysis. 2011; 2:41-51. https://doi.org/10.1016/j.irfa.2010.10.003

17. Jacobson $\mathrm{R}$ and Aaker D. Myopic management behavior with efficient but imperfect financial market: a comparison of information asymmetries in the U. S and Japan. Journal of Accounting Economics. 1993; 16:383-405. https://doi. org/10.1016/0165-4101(93)90033-C

18. Jiang L and Kim JB. Cross-corporate ownership, information Asymmetry and the usefulness of accounting performance measures in Japan. The International Journal of Accounting. 2000; 35:85-98. https://doi.org/10.1016/S0020-7063(99)00029-1

19. Kothari SP, Li X and Short JE. The effect of disclosures by management, analysts, and business press on cost of capital, return volatility, and analyst forecasts: A study using content analysis. The Accounting Review. 2009; 84:1639-70. https://doi. org/10.2308/accr.2009.84.5.1639

20. McGuire ST, Wang D and Wilson R. Dual class ownership and tax avoidance. The Accounting Review. 2014. In-Press. https:// doi.org/10.2308/accr-50718

21. Mayberry MA, McGuire ST \& Omer TC. Smoothing taxable income, tax avoidance, and the information content of taxable income, Working paper, Texas A\&M University. 2012.

22. Mojtahedzadeh V, Abu Hamza M, Mirza’i Mohammad M. The Effect of Corporate Disclosures on Tax Evasion in Firms Accepted in Tehran Stock Exchange. Quarterly Journal of Empirical Accounting Research. 2015; 4(3):1-21.

23. Mousavian Hamid Reza, Kordestani Gholamreza. Competition among knowledgeable investors for confidential information and information asymmetry pricing. 2013; 1(2):127-44.

24. Myers SC. Determinants of corporate borrowing. Journal of Financial Economics. 1997; 5:147-75. https://doi. org/10.1016/0304-405X(77)90015-0 
25. Plumlee MA. The effect of information complexity on analysts' use of that information. The Accounting Review. 2003; 78:27596. https://doi.org/10.2308/accr.2003.78.1.275

26. Pourheidari O, Burhani Nejad S. Investigating the Impact of Corporate Governance Principles on Tax Management in Firms Listed in Tehran Stock Exchange. Audit Knowledge. 2012; 12:49.

27. Rego S. Tax avoidance activities of U.S. multinational corporations. Contemporary Accounting Research. 2003; 20:805-33. https:// doi.org/10.1506/VANN-B7UB-GMFA-9E6W

28. Sun L, Rath S. Fundamental determinants, opportunistic behavior and signaling mechanism: An integration of earnings management perspectives. International Review of Business Research Papers. 2008; 4(4):406-20.

29. Rahmani Ali, Arbabi Bahar Zahra. The Relationship Between Diagnostic Taxes and Expressions With Profit Management. Empirical Accounting Research. 2013; 12:61-84.
30. Richardson V. Information asymmetry and earnings management: Some evidence. Review of Quantitative Finance and Accounting. 2000; 15:325-47. https://doi.org/10.1023/A:1012098407706

31. 31. Rustaei DM, Dianti E, Bani Z, Bahman M. The Relationship Between Corporate Trading Strategy and Tax Avoidance Level in Firms Accepted in Tehran Stock Exchange. Tax Release. 2015; 73:25.

32. Scott WR. Financial Accounting Theory. Third Edition. Pears Education. Canada. 2003.

33. Venkatesh PC and Chiang R. Information Asymmetry and the Dealers Bid-Ask Spread: A Case Study of Earning and Dividend Annoucements. The Journal of Finance. 1986; 41:1089-102.

34. Wang X. Tax Avoidance, Corporate Transparency, and Firm Value. Available at 2010. www.ssrn. Com. https://doi.org/10.2139/ ssrn. 1716474 